\title{
Revolução e Nihilismo em Raízes do Brasil, 1936
}

\author{
Damião Farias*
}

Resumo: O artigo aborda o tema "Revolução", analisado por Holanda em Raízes do Brasil (1936). A leitura foi mediada pela filosofia de Nietzsche, onde exploramos as noções de má consciência, ideal ascético e as críticas à modernidade. Além de duas referências explícitas ao filósofo, as abrangentes noções nietzschianas subsidiam as avaliações de Holanda sobre os "novos tempos" no Brasil. No entanto, a crítica do brasileiro foi direcionada àquelas "superfetações liberais", dado o seu caráter exógeno às tradições brasileiras. Em contrapartida, considerou positivos os valores do personalismo, subjacentes ao nosso modo de vida, favoráveis à criação de forma política concernente à sociedade.

Palavras-chave: revolução; nihilismo; Nietzsche; Raízes do Brasil; Sérgio B. de Holanda.

O tema da "Revolução", relacionado aos processos históricos de transformações na sociedade brasileira nos séculos XIX e XX é bastante explorado na fortuna crítica de Raízes do Brasil. Em sua

\footnotetext{
* Professor da Universidade Federal da Grande Dourados (UFGD), Brasil. Correi eletrônico: damiaofarias@ufgd.edu.br

ORCID: https://orcid.org/0000-0002-5718-730X
}

Cad. Nietzsche, Guarulhos/Porto Seguro, v.41, n.3, setembro-dezembro $2020 \mid 193$ 
maioria e atentos à última versão da obra de Holanda, cristalizada em na $5^{\text {a }}$ edição de 1969, os comentadores e intérpretes apontam os impasses do autor, sobretudo, em seu último capítulo intitulado "Nossa Revolução", a respeito dos indícios ou proposições políticas presentes em Raízes do Brasil.

Nossa estratégia de análise pretende alcançar outros resultados, também parciais, ao assumir como referência de leitura a primeira versão do Livro, publicada em 1936 (bastante modificada nas edições posteriores). Com essa estratégia, talvez, possamos apresentar alguma contribuição para melhor entendimento da obra. Para tanto, iremos acompanhar as tessituras de Holanda, em especial os seus possíveis vínculos com a filosofia do alemão Nietzsche.

Em artigo intitulado "Cordialidade..." , procuramos acompanhar a avaliação psicológica do típico homem brasileiro. No caso, e segundo sugeria o autor de Raízes do Brasil, seguimos como importante indício, apresentado na obra, a frase extraída de Assim Falou Zaratustra (2018) de Friedrich Nietzsche: "Vosso mau amor de vós mesmos fez de vosso isolamento um cativeiro" (Za/ZA, I, Do amor ao próximo, KSA 4.78; apud HOLANDA, 1936, p. 103). ${ }^{2}$

Neste momento, pretendemos desdobrar as análises de Holanda sobre o "Homem Cordial", ao debruçarmos sobre os dois últimos capítulos do livro, intitulados "Novos Tempos" e "A Nossa Revolução". Há no último capítulo duas referências ao filósofo alemão Nietzsche. Uma na forma de epígrafe e outra na forma de nota explicativa. Voltaremos às duas referências ao longo deste artigo. Parece-nos que é possível utilizar, ainda, outras chaves interpretativas nietzschianas para a compreensão dos dois capítulos finais, nos quais Holanda pretende demonstrar aos leitores outras perspectivas sobre o "chão cultural", do qual brotara o "homem cordial" no século XIX e que

1 Cordialidade: crítica nietzschiana e ambivalência do homem "moderno" brasileiro em Raízes do Brasil (1936), ainda inédito.

2 Uma tradução mais coerente para com a filosofia de Nietzsche me parece ser àquela apresentada por Paulo César de Souza: "Vosso mau amor a vós mesmos transforma em prisão vossa solidão” (NIETZSCHE, 2018, p. 58); Za/ZA I, Do amor ao próximo, KSA 4.78. 
caracterizava o brasileiro ainda no século XX.

Três noções vinculadas à filosofia de Nietzsche parecem promissoras às nossas intenções: 1) o espírito de negação ou nihilismo, 2) a má consciência, e 3) os ideais modernos simpáticos ou da moral da compaixão.

Mas, antes de abordá-las, apresentaremos a ideia da "Nossa Revolução" elaborada por Holanda. Ela está presente, sobretudo, no último capítulo, no entanto, sua melhor compreensão não prescinde a um olhar mais amplo sobre o conjunto da obra. Consideramos que Raízes do Brasil está organizado em duas partes, sendo a primeira composta pelos quatro capítulos iniciais e a segunda pelos três capítulos finais. Na primeira parte, Holanda realizou uma interpretação da formação do Brasil colonial, tendo, como eixo principal, os desdobramentos da cultura da personalidade gestada pelos povos ibéricos desde tempos imemoriais. Na segunda parte, lemos as análises dos chamados novos tempos, ocupando o centro das discussões a figura do "homem cordial" e suas interações com o advento das chamadas ideologias modernas, centradas no liberalismo democrático.

De acordo com Holanda, a passagem entre um período e outro se caracterizou por intensa crise societária. Seria a "Nossa Revolução" tão profunda quanto lenta. Ela é analisada como processo de transformações, sobre o qual o conceito moderno de "revolução" seria, aparentemente, insuficiente para esclarecê-lo.

É necessário recuperarmos aqui algumas ideias apresentadas no referido artigo, ainda inédito, intitulado "Cordialidade...". Para produzir o efeito do vigor pretendido com as noções de crise e ruptura que apresentava, o autor lançou mão de uma referência artística, a tragédia Antígona de Sófocles. ${ }^{3}$ Holanda esforça-se para

3 É provável que Sérgio B. de Holanda tenha se inspirado em Hegel, Fenomenologia do Espírito (1807), para a imagem construída sobre a crise brasileira, utilizando-se da tragédia Antígona. Hegel quis demonstrar a superioridade da eticidade na modernidade europeia em relação à Grécia Clássica. Em Holanda as perspectivas são bastante distintas como veremos. Conforme: SCALDAFERRO, Maikon Chaider Silva. A família e o Estado: Antígona, Hegel e as raízes do Brasil. In: Griot: Revista de Filosofia, Amargosa, Bahia - Brasil, v.14, n.2, dezem-

Cad. Nietzsche, Guarulhos/Porto Seguro, v.41, n.3, setembro-dezembro $2020 \mid 195$ 
esclarecer as interações que a referida obra trágica possuía na vida cultural dos gregos, de significado superior à mera noção de divertimento do público. Pois que, como possivelmente a compreendia Holanda, a apresentação das tragédias se integrava de maneira relevante às atividades públicas da Pólis, ao universo agonístico da cultura e da formação da cidadania grega. A encenação das obras dos artistas trágicos, em concorridos concursos promovidos pelo Estado grego, remetia às reflexões fundamentais sobre as relações dos cidadãos gregos com a "cidade" e, inclusive, ponderava a existência humana no interior de uma ordem cosmológica, com as razões e obrigações para com os deuses. A tragédia revelava, desse modo, sempre a recriação de afecções arquetípicas junto ao seu público.

Holanda utiliza o confronto entre Creonte e sua sobrinha Antígona, para realçar o caráter significativo de crise e ruptura, talvez a mais dramática de todos os tempos da história da humanidade. A intenção do autor é marcar o rompimento e a passagem, de uma vida social e histórica, centrada nos poderes, relações e obrigações familiares, para outras formas na sociedade, nas quais se agigantava e se sobrepunha o poder de Estado, cujo caráter abstrato, em nome da Pólis e dos interesses de seus cidadãos, se opunha ao domínio da lógica corpórea dos sentimentos domésticos.

O conflito entre Antígona e Creonte é de todas as épocas e preserva a sua veemência ainda em nossos dias. Em todas as culturas, o processo pelo qual a lei geral suplanta a lei particular, faz-se acompanhar de crises mais ou menos graves e prolongadas, que podem afetar profundamente a estrutura das sociedades. $\mathrm{O}$ estudo dessas crises constitui um dos temas fundamentais da história social (HOLANDA, 1936, p. 94).

É possível afirmar, também, que o autor investe na ideia de proximidades ou, talvez, na presença de restos de antiguidade, via cultura ibérica, na vida dos portugueses do Brasil, com o 
objetivo de demonstrar a profundidade de sua acepção de ruptura histórica, ao passo em que expõe uma diferença em relação aos processos revolucionários modernos da Europa e dos Estados Unidos.

Assim, e também com o intuito de reforçar o caráter holístico da referida ruptura, Holanda utiliza como exemplo, próximo temporalmente da crise brasileira, a passagem do regime de trabalho corporativo, na qual "[...] mestre e seus aprendizes e jornaleiros formavam como uma só família, cujos membros se sujeitam a uma hierarquia natural, mas que partilham das mesmas privações e confortos [...]" (HOLANDA: 1936, p. 94), para o regime moderno de produção capitalista, que ao separar empregados e empregadores, produziu a luta de classes, fez desaparecer as relações humanas e toda a esfera de intimidade reinante outrora. Criou, por outro lado, a abstração das relações sociais, ao tornar a figura do trabalhador mero número funcional. Introduziu, ainda, no mundo da produção de mercadorias, um sentimento de distanciamento e irresponsabilidade por parte dos empregadores em relação aos seus empregados, seja na remuneração, ou nas condições de trabalho.

Além de apresentar o caráter amplo daquele "cataclismo" na história da humanidade, Holanda demarca uma especificidade importante, que já fora tematizada nos capítulos anteriores de Raízes do Brasil. A ruptura brasileira não possuía o mesmo significado, os mesmos desdobramentos dos acontecimentos revolucionários dos países da Europa e da América do Norte. A crise da passagem do trabalho corporativo para o assalariamento seria, ainda, uma pálida ideia do monstruoso cataclismo que substitui os "laços de afeto e de sangue" por relações abstratas.

De todo modo, seria possível encontrar restos daquele poderio familiar ainda no mundo moderno a resistir, mesmo nas grandes cidades, às novas condições de vida. Verifica-se, além disso, que a persistência, daquele modo antigo, era maior e efetiva onde predominara o tipo de família de poder patriarcal, como no caso 
brasileiro, o que reforçaria a envergadura ímpar de nossa evolução histórica.

Precisamente, pela sobrevivência daqueles restos de cultura, de poder familiar antigo, nota-se o caráter lento e gradual da revolução brasileira. Holanda situa o ano de 1888, com o fim do regime de escravidão e suas decorrências, como momento de alteração decisiva na lenta transformação, pois segundo o autor, a revolução brasileira não tivera um acontecimento extraordinário, mas caracterizava-se por um processo evolutivo, desde a vinda da Família Real portuguesa para o Brasil em 1808. Daquela época adiante, uma sorte de mudanças sempre mais intensas tiveram lugar e alcançaram ritmo extraordinário na década de 50 do século XIX. Elas ainda, no tempo do autor, em pleno século XX, tinham o seu lugar.

O significado mais vívido desse processo histórico foi a passagem do domínio secular do poder rural para o poder urbano. Holanda considerou o fenômeno da urbanização, de longe, a ocorrência mais notável das alterações na sociedade brasileira. Aquela singularidade que até então definia a história de nossa sociedade, ou seja, a hipertrofia do mundo rural conheceria sua decadência e, ao mesmo tempo, a submissão das cidades ao poder do campo entraria em movimento de inversão dessa polarização.

Holanda argumenta que o declínio da produção açucareira, especialmente na Região Nordeste, indicara a direção das novas relações sociais em construção, não obstante o lapso de grandes domínios escravistas na região fluminense e no Vale do Paraíba na primeira metade do XIX. As ocorrências favoráveis à expansão das cidades e dos negócios urbanos incrementaram a presença de agentes portadores de uma nova racionalidade e práticas sociais, notadamente nas regiões novas da produção de café no Estado de São Paulo, após meados daquele século.

Apesar de serem considerados acontecimentos categóricos, a abolição da escravatura e a Proclamação da República que, supostamente, criaria as formas institucionais articuladas às tendên- 
cias sociais que se afirmavam, não foram suficientes para separar os tempos antigos dos novos. Desse fenômeno, resultara na vida brasileira todo um colorido especial, produzido por ambivalências nos costumes e comportamentos do homem brasileiro; polarizado e cindido entre as lógicas típicas dos laços de sentimento e sangue, da pessoalidade, produzidas no seio do pátrio poder doméstico, e aquelas próprias das relações racionalizadas, impessoais e abstratas do mundo moderno capitalista e urbano.

Com as indicações dos parágrafos acima e os problemas aventados, podemos, agora, buscar melhor compreensão das razões ou das raízes desse impasse que repercutia negativamente sobre outra dimensão da vida brasileira de nação independente, ou seja, em nossas capacidades para criar as formas de organização social adequadas à superação da desordem distintiva, à qual parecíamos condenados. Ao bom entendimento da questão, o autor nos obriga a retomar a reflexão sobre os primórdios de "Nossa Revolução".

Para Holanda, a passagem do século XVIII para o Século XIX, relacionada a grandes acontecimentos do Ocidente, daria inicio ao movimento de mudança na história da ex-colônia portuguesa, como afirmamos anteriormente. Mas, de modo inusitado, ao contrário e no interior da imagem geral criada para o caráter lento e gradual da revolução brasileira, o autor delineia um aspecto ou dimensão que a caracteriza como "transição brusca", com graves repercussões na psicologia dos povos.

Na passagem do domínio rural para o urbano, em decorrência das necessidades de formação do novo arcabouço de poder estatal, a ser construído em escala nacional, bem como, das exigências em responder aos variados negócios e estruturas em crescimento, e considerando não possuirmos na formação da gente brasileira, os indivíduos típicos de uma cultura moderna "americanista", racionalista e liberal, foram os próprios antigos senhores e filhos de senhores impelidos, pela força dos acontecimentos e racionalidades inerentes às instituições que se formavam, a assumirem as funções 
demandadas na nação independente.

De acordo com Holanda, o recrutamento para as novas obrigações sociais ocorreu sobre os membros das antigas famílias senhoriais, cujo poder local sem peias para a tirania do chefe patriarcal constituía a força centrípeta de toda vida social no período colonial e amarrava sentimentalmente seus entes de modo profundo e poderoso.

A contiguidade que se estabelece no âmbito doméstico entre os membros de uma família desse tipo, tem seu correlativo psicológico bem determinado. $\mathrm{O}$ quadro familiar é, nesse caso, tão poderoso e exigente, que acompanha aos indivíduos mesmo fora do recinto doméstico. [...] A nostalgia desse quadro compacto, único e intransferível, onde prevalecem sempre e necessariamente as preferências fundadas em laços afetivos, deixou vestígios patentes em nossa sociedade, em nossa vida política, em todas as nossas atividades (HOLANDA: 1936: 88-89)

Foi esse homem que, com tal perfil psicológico, recrutado ao nosso mundo rural, dominou os variados movimentos, acontecimentos e as formulações políticas desde a precipitação da crise do antigo sistema colonial no Brasil. Sobre as variadas nuances que denotariam a presença desses sujeitos sociais nas novas conjunturas históricas que eram criadas pela "Nossa Revolução", queremos esboçar uma interpretação que, em primeiro momento, aparece como uma doença, enfraquecimento substantivo dessa figura, cuja centralidade decidia os rumos da existência brasileira.

Holanda expõe que esses homens pegos quase de surpresa, não podendo resistir plenamente ao inusitado estado de coisas, e ainda sem as habilidades e as capacidades necessárias para viver em conformidade com as novas realidades da história, sofreram a nostalgia e o desamparo dos deleites e lazeres da vida rural. Criou-se um fosso entre o nosso ethos e o nosso eros, e a realidade em que viviam passou a ser infalivelmente a "dura", a "triste" realidade. Esse não foi um fenômeno passageiro, e deve ser avaliado como maior do que sentimentos de derrotas em expe- 
riências fracassadas. Os nossos homens foram afetados de modo incisivo: "A existência rigorosa e abstrata das cidades, deve ter estimulado em nossos homens uma crise subterrânea, voraz. Os melhores, os mais sensíveis, puseram-se a detestar francamente a vida, o 'cárcere da vida', para falar na linguagem figurada do tempo" (HOLANDA: 1936: 124).

Entendemos que o autor abre no texto possibilidades de interpretarmos essas passagens, como uma espécie de formação e desenvolvimento de um mal-estar, e, talvez, mais precisamente, de uma má consciência que se desdobraria, também, em outros comportamentos tipicamente doentios, decadentes, conforme a filosofia de Friedrich Nietzsche. Para análise desses temas, utilizaremos o filósofo alemão a respeito do referido fenômeno da má consciência e do espírito de negação. Salientamos que a noção "má consciência" era, no período, preocupação mais ou menos comum, a partir da disseminação dos textos de Sigmund Freud. Foi tema, por exemplo, no "Manifesto Antropófago" de Oswald de Andrade (1927), e de um conto intitulado "Viagem a Nápoles" de Sérgio B. de Holanda, escrito em 1931, tendo sido ambos os modernistas, leitores de Nietzsche.

A abordagem nietzschiana sobre os temas apontados foi elaborada de modo significativo no livro "Genealogia da Moral" (1887), na Segunda Dissertação com o título “Culpa', 'má consciência' e coisas afins". Nietzsche formula uma "hipótese" sobre o surgimento da má consciência. Ela fora criada pari passu com a formação do "Estado" (compreendido como força organizadora, empreendedora e externa, provavelmente de hordas de grupos guerreiros, que se impuseram pela força e violência sobre massas humanas maiores em quantidade do que o número de invasores). Essa força plástica guerreira, contra a qual dificilmente se poderia levantar resistência, fora responsável por erguer barreiras e toda sorte de impedimentos, de modo a obrigar o conjunto da vida social a determinadas formas de vida. Dar forma, conformar uma matéria, 
seria o espírito da força tirânica, voluntária e arbitrária, tal qual um artista se impõe sobre um bloco amorfo de bronze.

Outro fenômeno surgiu no momento da gênese da sociedade e do Estado. Os livres instintos da violência, da guerra, da destruição e da crueldade que antes não tinham peias e freios antinaturais, e eram os modos do exercício da vontade de conquista e de domínio, foram constrangidos a viver na paz da comunidade, daquele momento em diante. No entanto, esses instintos do antigo homem bárbaro ou selvagem anteriormente acostumado à vivência em liberdade na natureza e a uma vida de errâncias e volúpias por grandes aventuras e perigos são, no seio da comunidade estável, impedidos de descarregarem-se para fora, contra ou em direção à apropriação dos seus objetivos. Eles "voltam-se para dentro - isto é o que chamo de interiorização do homem: é assim que no homem cresce o que depois se denomina sua 'alma"' (GM/GM, II, 16, KSA 5.322). Dessa declaração de guerra aos antigos e dominantes instintos, nasceu a má consciência, o remorso (a mordida na consciência):

Esse homem que, por falta de inimigos e resistências exteriores, cerrado numa opressiva estreiteza e regularidade dos costumes, impacientemente lacerou, perseguiu, corroeu, espicaçou, maltratou a si mesmo, esse animal que querem "amansar", que se fere nas barras da própria jaula, este ser carente, consumido pela nostalgia do ermo, que a si mesmo teve de converter em aventura, câmara de tortura, insegura e perigosa mata - esse tolo, esse prisioneiro presa da ânsia e do desespero tornou-se inventor da "má consciência" (GM/GM, II, 16, KSA 5.323).

O filósofo alemão assevera que esse voltar-se sobre si mesmo tratar-se-ia, no fundo, de um mesmo tipo de força ordenadora e ativa na instituição das formas sociais e estatais, somente que a matéria sobre a qual se debruça é inteiramente outra: o próprio homem. De tamanha crueldade para consigo, nasceram os delicados ideais humanos, os mais delgados como os ideais de beleza, os mais enigmáticos como os do não egoísmo, do desinteresse e do próprio 
auto sacrifício.

Nietzsche aduz em sua hipótese um terceiro elemento de análise. Em um período posterior àqueles tempos da história da humanidade, um período intermediário, conforme define o filósofo, nos grupos sociais onde predominava forte e exuberante raça humana, nomeadamente nas estirpes nobres, com sua cultura aristocrática, correspondia um quanta de forças, formas e produtos também exuberantes desse inferir do homem consigo. É o que se nota nas qualidades dos deuses das estirpes potentes, espelhos da autocompreensão do homem nobre: vitoriosa, venerada e temida. Nesses casos, entre os gregos por exemplo, os homens honravam suas dívidas a seus antepassados e deuses, por meio de contínuos empoderamentos e feitos gloriosos. Quanto mais realizavam em favor da estirpe, melhor era a própria satisfação e a consciência de terem resgatadas as suas pendências.

Não restava, assim, entre esses tipos humanos, o ensombrecer-se de si e da vida em geral, devido à dívidas não restituídas junto às divindades: "o animal no homem se sentia divinizado e não se dilacerava, não enraivecia consigo mesmo!” (GM/GM, II, 23, KSA 5.333).

Por outro lado, entre as nobrezas guerreiras, o erro e o infortúnio acaso existentes, não eram motivos para a condenação de si e muito menos da espécie. De modo muito diferente a isso, essas classes de ocorrências eram ponderadas como falta de prudência e conhecimento, de observação cautelosa e segura. E devido a essa avaliação, recomendava-se que o caminho natural a ser trilhado era a superação dos motivos e causas das desventuras do destino, que frequentemente acometiam os humanos. E, em último caso, atribuía-se a responsabilidade aos deuses!

De acordo com Nietzsche, fenômeno diverso ocorreria entre os grupos humanos escravizados e servos. Esses, identificados por uma vida decadente, frágil e doentia, sensivelmente distinta daquelas experiências de tempos e contingentes humanos mais sau- 
dáveis, incorporaram a dor e o sofrimento daquele "inferir consigo mesmo", como culpa e pecado. Entre tais grupos, em determinadas épocas e lugares de domínio político cultural sacerdotal, verificou-se uma moralização das noções de erro e castigo. Os infortúnios pessoais e coletivos foram vistos como calamidades viciosas, o erro em si, atos condenáveis que arrastam consigo o seu autor ou responsável e, por vezes, a própria comunidade. A condenação ocorre por meio de avaliações comparativas a comportamentos ideais virtuosos, que se estendem em espiral de moralidade ascética, cujo vértice figura o homem santo.

A condição histórica, nos casos apontados no parágrafo anterior, é o desaparecimento da cultura aristocrática, daquela força de vontade que molda a si mesma e se vê como centro de referência e de reverência. Esse rebaixamento do homem produziu, como contraparte, uma inevitável intangibilidade do divino, frente ao qual o humano já não poderia mais saldar suas dívidas, tornando-se um ser desprezível e culpado. Sua realidade e natureza de nada mais valem, sendo elas inteiramente condenáveis e subordinadas a ideais nihilistas, ao anseio do "nada", anseio de um "Ser-outro". Presente em muitos povos e culturas, a décadence atingira seu ápice com o ideal cristão e seus desdobramentos nas ideologias modernas do Ocidente.

Portanto, com moralização dos costumes a noção de "má consciência" ganha um sentido interpretativo distinto. Nota-se para além da incorporação da dor, a sua fusão e naturalização com as noções de pecado e culpa. Nietzsche aduz a observação de que seria ilusório que o crescimento do ateísmo nos tempos modernos, nos livrasse desta imensa e terrível doença, a maior que assola a humanidade. Pois, o declínio do deus cristão no Ocidente foi substituído por outros ideais ascéticos, tão ou mais moralizantes e negadores da vida quanto o ideal cristão.

\section{$O$ amor às formas fixas}


Podemos retomar as considerações de Holanda em Raízes do Brasil, para aduzir, às reflexões de parágrafos anteriores, outras características sintomáticas, daquele viver triste e em cárcere, e da relativa anomia que tomou conta do homem brasileiro, no período de nascimento e formação da nação. Desse modo, é tratada a condição doentia de nosso romantismo, como experiência artística incapaz de criar algo realmente novo, que já não estivesse nas obras de artistas e intelectuais europeus. Não obstante o papel valioso que teve por expressar aspectos brasileiros, o movimento romântico reforçou esta tendência ao pessimismo, e a uma sentimentalidade de negação; a literatura romântica foi o corolário à "superfetação na vida brasileira."

Tornando possível a criação de um mundo fora do mundo, o amor às letras não tardou em instituir um derivativo cômodo para o horror à realidade, à nossa realidade. Não reagiu contra ela, de uma reação sã e fecunda, não tratou de corrigi-la ou de dominá-la; esqueceu-a, simplesmente, ou detestou-a, provocando desencantos precoces e ilusões de maturidade (HOLANDA, 1936, 125).

Chamamos a atenção para o sentido da inadaptabilidade, fraqueza, falta de virilidade que o texto apresenta. $\mathrm{O}$ autor imagina a possibilidade de outro tratamento para a realidade de então, que se caracterizasse por uma "reação sã" que a fecundasse, a dominasse, estabelecendo-se como vontade de novas e adequadas formas. Esse foi o estado fisiológico e psicológico, do corpo intelectual, artístico e literário do principal movimento artístico brasileiro do século XIX. Pensamos ser possível relacionar essa avaliação do historiador brasileiro com a sequência de ideias de Nietzsche que apresentamos anteriormente, haja vista que em Holanda, aquela condição se desdobra como sintomas de "horror à realidade" e é interessante frisar esse "horror" com o qual o autor distingue o pathos brasileiro. ${ }^{4}$

4 Estas noções e avaliações que Holanda propusera e que apresentamos nos parágrafos anteriores, aproxima a análise do historiador brasileiro dos temas do "mal estar" ou da "má cons-

Cad. Nietzsche, Guarulhos/Porto Seguro, v.41, n.3, setembro-dezembro $2020 \mid 205$ 
Sérgio Buarque elabora uma imagem cujos contornos destacam e iluminam certos aspectos de todo o comportamento de nossos intelectuais. Esse sentimento estaria, ainda, relacionado a outro desdobramento, em passo nihilista, à criação de um mundo fora do mundo, "um derivativo cômodo", para aqueles incapazes de verdadeiramente agir sobre a realidade, o que revelaria a "mesma fragilidade, a mesma inconsistência íntima, a mesma indiferença, no fundo ao corpo social; todo pretexto estético pode servi-lo de conteúdo" (HOLANDA, 1936, 126).

Por conseguinte, as produções e manifestações intelectuais, artísticas e políticas tinham este corolário de sonho e imaginação artificiosa destacadas da vida brasileira.

Comparsas desatentos do mundo que habitávamos, quisemos viver fervorosamente contra nós mesmos, viver pelo espírito e não pelo sangue. Como Plotino de Alexandria, que sentia vergonha pelo próprio corpo, acabaríamos por esquecer tudo quanto fizesse pensar em nossa própria riqueza emocional, a única força criadora que ainda restava, para nos submetermos à palavra escrita, à retórica, à gramática, ao Direito abstrato (HOLANDA, 1936, 126).

A citação a Plotino de Alexandria bem procura dar conta da noção de "horror" ao corpo nacional, desviando o olhar da extraordinária e específica riqueza emocional do homem brasileiro, a única força potencialmente criadora entre nós. No desencanto, no mal-estar e no interior da construção do nihilismo, à brasileira, o autor chama a atenção para o pendor às convicções e aos sistemas de ideias que se apresentam, aos homens brasileiros, como perfeitas congruências e notabilidades. Segundo Holanda (1936, p. 118): “Um amor pronun-

ciência", que em Nietzsche foi apresentado como desdobramentos da imposição do "viver em comunidades" e em necessária condição de paz; dos grupos humanos serem obrigados a abandonar antigos modos de vida, de violências e guerras, represando instintos outrora dominantes. Ainda, em decorrência desses processos históricos, Nietzsche apresentou dois caminhos possivelmente trilhados por aquelas comunidades: a) o nascimento de culturas aristocráticas entre as estirpes mais fortes; b) a produção de valores ascéticos, quando os homens já não possuem ou não alcançam forças para o desabrochar de uma cultura nobre. 
ciado pelas formas fixas e pelas leis gerais, que circunscrevem a realidade complexa e difícil dentro dos nossos desejos, é dos aspectos mais constantes e significativos do caráter do brasileiro".

Nossos movimentos intelectuais teriam como relevo próprio, a predileção para fórmulas mentais bem acabadas com frase lapidar, pensamento inflexível, capazes de circunscrever a fluidez e a complexidade da realidade da vida nacional. Nesse contexto, podemos compreender, a partir de Holanda, o sucesso alcançado entre nós pelo positivismo, dadas às suas qualidades ou pretensões em subjugar o tempo a um determinismo progressista que, ao fim e ao cabo, acabaria por fatalmente ajustar a vida social. Para os "negadores" positivistas bastava esperar, tendo feito o proselitismo de suas convicções, que a realidade a elas se amoldasse.

O instinto negador presidira os negócios públicos nacionais, mais nitidamente com o passar dos tempos, da fundação da República. No Império, segundo Sérgio Buarque, desenvolveu-se uma monarquia tutelar, como desenrolar da inexperiência do brasileiro como povo nacional, que mais se coadunava com a vida social agrária e patriarcal. Mesmo as representações partidárias, no XIX, foram reinvenções visíveis das antigas disposições de "luta e solidariedade" entre facções. Enquanto os propagandistas republicanos, e seu espírito negador, quiseram fugir a essas formas antiquadas brasileiras. Para eles,

[...] o Brasil devia entrar em novo rumo, porque "se envergonhava" de si mesmo, de sua realidade biológica. Aqueles que pugnavam por uma vida nova representavam, talvez, ainda mais do que os seus antecessores, a ideia de que o país não pode crescer pelas suas próprias forças naturais; deve formar-se de fora para dentro, deve merecer a aprovação dos outros (HOLANDA, 1936 p. 131).

Mas, em verdade, o positivismo seria apenas o corolário de uma conjunção de forças e ideias mais vastas presentes no meio brasileiro: o liberalismo. Quisemos, com as ideias liberais, evadir da realidade, porque elas forneciam a aparência de dignidade que 
faltava em nossa vida adolescente política e social. No entanto, eles se esqueciam de que as especulações liberais mal se adequavam ao país. A ideologia liberal e seus princípios focados em uma perspectiva antinatural da pessoa, do impessoalismo democrático, possuíam pouca convergência com os móveis fundadores da cultura brasileira, exatamente aquelas tradições que, da Ibéria para cá, conformaram as relações sociais, públicas e privadas, interpretadas na noção de personalismo. ${ }^{5}$

Esquecendo-se de nossas tradições portuguesas e mestiças, nossos publicistas e teóricos, pensaram estar em boa companhia e tomaram noções estrangeiras como próprias à vida brasileira. $\mathrm{Na}$ verdade, para uma futura vida brasileira, pois eles anseiam que o porvir lhe reservasse correção, adequação aos termos de outras realidades, mais auspiciosas, mormente advindas da Europa ou dos Estados Unidos, utilizadas de parâmetro para avaliação e julgamento de nossa gente e das instituições brasileiras. "O prestígio moderno e provavelmente efêmero das superstições liberais e protestantes parece-lhes definitivo, eterno, indiscutível e universal; elas valem como paradigma para julgarem do nosso atraso ou de nosso progresso" (HOLANDA, 1936, p. 128). ${ }^{6}$

Notamos, todavia, que a crítica preliminarmente elaborada sobre as tentativas de adequação fantasmagórica de nossas instituições e de nossas formas culturais a um constructo intelectual

5 Nesse ponto da argumentação foi que Holanda introduziu a famosa e polêmica frase: "A democracia no Brasil foi sempre um lamentável mal-entendido". HOLANDA: 1936, 122. Pretendemos explorar este aspecto, dentre outros, do texto buarqueano em outro artigo em elaboração, intitulado "Forma, Cultura e Estado em Ráizes do Brasil, 1936".

6 Faz-se necessário chamar a atenção para a conjuntura histórica da escrita de Raízes do Brasil. Os anos trinta estavam marcados pelo desencanto e tentativas de superação das formas institucionais e das práticas sociais, políticas, culturais e econômicas características do liberalismo clássico. Seja na América do Norte, na América do Sul, na Europa, nos países capitalistas ou na União Soviética, nas mais diversas dimensões buscava-se alternativas à crise civilizatória ocidental que veio à tona com a Primeira Guerra Mundial (1914-1918) e que ganhou sinais de dramaticidade com o déblace econômico pós-1929 e a ascensão do nazi-fascismo. Holanda, por suas experiências no movimento modernista brasileiro, pelos acontecimentos no Brasil após 1930 e, ainda, pelo período de correspondente de jornalismo na Alemanha, nos anos de 1929 e 1930, foi observador privilegiado desse contexto e de tais acontecimentos. 
isolado da vida sentimental do brasileiro passou a acentuar, agora, negativamente, as "superstições liberais e protestantes", cujo prestígio provavelmente seria efêmero.

A crença em construções intelectuais, em especial legislativa a corrigir e dar novo curso aos povos, não seria somente uma ilusão a nublar o espírito brasileiro e de americanos que nos são próximos. A crítica de Holanda visava, de modo mais abrangente, os fundamentos presentes nas formas ideológicas e políticas de todo o Ocidente, ao se dirigir contra o "mito do progresso". Do mito progressista teria surgido um conjunto de ideologias assemelhadas como o contismo, o spencerismo e o marxismo. Todas elas nascidas no interior do liberalismo democrático e das ideias abstratas a ele conexas, como as concepções dos "famosos direitos humanos", que aliadas a outras noções suportavam as chamadas revoluções modernas. Destarte, o revolucionarismo do século XIX era fruto do grande pecado daquele século que quis fazer "preceder o mundo das formas vivas do mundo das fórmulas e dos conceitos". (HOLANDA, 1936, 146).

De modo severo e vigoroso, o autor argumenta contra o formalismo na gênese das teorias liberais. Ao contrário do que se poderia supor sobre uma aproximação dos valores do "homem cordial" com os dogmas liberais, Holanda contra argumenta que no liberalismo a teoria da bondade natural do homem é essencialmente neutra, e um simples argumento. Não poderíamos imaginar que ela encerrasse qualquer simpatia pelo gênero humano, ou mesmo a cada pessoa considerada individualmente (HOLANDA, 1936, 155). Essa interpretação liberal da bondade natural do homem, que seria um dos seus fundamentos, apresenta dissonâncias em relação à perspectiva da cordialidade do homem brasileiro, como também repousaria em um paradoxo, considerando que seria absurdo desejar, conforme a famosa frase de Bentham, "a maior felicidade para o maior número". (HOLANDA, 1936, 156). Haveria, na frase, apenas uma fórmula que quer expressar um equilíbrio dos egoísmos, mediados pela ideia da 
impessoalidade e, portanto, distante da noção de amor ou qualquer convivência que se sustente em afetos. Pois, “amar alguém é amá-lo mais que aos outros". (HOLANDA, 1936, p. 156).

Mas, de qual lugar o autor está interpretando? Nos parece, em divergência com boa parte da fortuna crítica de Raízes do Brasil, que não seria o melhor caminho apontar no texto buarqueano uma aproximação com o liberalismo democrático. Holanda foi enfático ao condenar a existência liberal entre os brasileiros: "no terreno político e social o liberalismo revelou-se entre nós antes um destruidor de formas preexistentes do que um criador de novas; se foi sobretudo uma inútil e onerosa superfetação;". (HOLANDA, 1936, p. 160). ${ }^{7}$

De outro modo, existem também interpretações que buscam aproximar as análises de Holanda às formulações do fascismo ou do varguismo no Brasil. Esse entendimento de Raízes do Brasil, à direita política, por vezes usa, além disso, a mediação da filosofia de Nietzsche que seria subjacente à obra, sem, no entanto, terem desdobrados análises mais consequentes. ${ }^{8}$

Não obstante as observações e acúmulos da crítica sobre as relações entre a filosofia de Nietzsche e o nazi-fascismo, ou às apropriações indevidas e falsificações do filósofo e sua obra, acreditamos que a própria leitura acurada da obra de Holanda poderia lançar algumas luzes sobre a questão. Para o autor, o fascismo europeu seria, nada mais nada menos, que o desenvolvimento de formas

7 O equívoco produzido por diversos autores, provavelmente fora provocado por Holanda, por meio das significativas alterações textuais em sua obra, nas segunda, terceira e quarta edições quanto ganhou a redação que hoje normalmente alcançam os leitores e intérpretes. Nesta última redação, de fato, pode se notar certo progressismo em várias passagens alteradas.

8 "Vocabulário e ideário mobilizados por Sérgio revelam, em meu entender, sua afinidade com a crítica, de caráter conservador e antidemocrático, ao liberalismo (e, nem é preciso dizer, às outras tendências ainda mais à esquerda do liberalismo). [...] Em meu juízo, essa argumentação é reiterada de modo significativo na abertura do célebre capítulo sobre "Nossa revolução". Pois aquela oligarquia e aquele elitismo estão em harmonia com o Friedrich Nietzsche citado em epígrafe ao capítulo final de Raízes do Brasil: 'Um povo perece, quando confunde seu dever com o conceito de dever em geral"' (Nietzsche, 1988 [1888ª , p. 117; Holanda, 1936, p. 133) (apud WAIZBORT, 2011, p.43). 
caudilhas de organização do Estado, na forma negativa da tese liberal, o seu outro lado, sem se afastar do campo das ilusões modernas progressistas. Holanda imagina ser possível e, talvez necessária, a superação de ambas as formas de organização estatal.

Conforme afirmamos anteriormente, as indicações sobre a presença subjacente, bem como, as referências explícitas da filosofia de Nietzsche na obra do historiador e ensaísta brasileiro, talvez sejam frutíferas para melhor compreensão da crítica do autor às teorias do liberalismo democrático.

No capítulo final de Raízes do Brasil, intitulado "Nossa Revolução", há duas citações do filósofo alemão. A primeira aparece na forma de epígrafe "um povo perece, quando confunde seu dever com o conceito de dever em geral" (AC/AC: 16, KSA 6. 182). Trata-se de uma frase do livro "O Anticristo" (1895). A segunda referência é uma nota afirmativa a um pensamento de Nietzsche sobre a impossibilidade em se constituir historicamente instituições, baseadas apenas na força do sentimento. No caso, Nietzsche usava o exemplo do casamento por amor para explicitar essa dificuldade relacionada ao definhamento do princípio da autoridade na modernidade (conforme aforismo 39 Crítica da modernidade, no capítulo Incursões de um extemporâneo) ${ }^{9}$. Holanda, por sua vez, recorre a essa formulação nietzschiana para refletir sobre as dificuldades do transbordamento emocional do homem cordial na criação de formas longevas, amplas e verdadeiramente articuladas à cultura brasileira. ${ }^{10}$

Ora, o citado aforismo ou seção, "Crítica da modernidade" (GD/CI, Incursões de um extemporâneo 39, KSA 6.140-142) encerra uma sequência de marteladas filosóficas às instituições, ideologias

9 NIETZSCHE, F. Crepúsculos dos Ídolos ou como se filosofa com o martelo. Tradução, notas e posfácio de Paulo Cezar de Souza. São Paulo: Cia das Letras: 2006 (GD/CI Incursões de um extemporâneo 39, KSA 6.140-142).

10 Esses e outros aspectos a respeito das críticas e possíveis transformações das formas institucionais brasileiras são analisadas no artigo "O problema da forma, da cultura e do Estado em Raízes do Brasil (1936)", ainda inédito. 
e valores do mundo moderno. Portanto, parece-nos que, para além do uso explícito que observamos em relação ao declínio do princípio da autoridade, Holanda valeu-se do texto nietzschiano para formular sua própria interpretação crítica e abrangente das tradições liberais, conforme inferimos em parágrafos anteriores. ${ }^{11}$

Sem o compromisso e a pretensão de uma interpretação mais exaustiva e profunda das questões apontadas e, na verdade, com a intenção de deslindar a proximidade da análise de Holanda com a Filosofia de Nietzsche, apresentaremos na sequência um extrato exploratório dos aforismos de números 34 (Cristão e anarquista), 35 (Crítica da moral da décadence), 37 (Se nos tornamos mais morais), 38 (meu conceito de liberdade) e 39 (Crítica da modernidade) presentes no Capítulo "Incursões de um Extemporâneo" do citado livro de Nietzsche.

No aforismo 34 (GD/CI, Incursões de um extemporâneo 34, KSA 6.132-133), Nietzsche aproxima as duas figuras (o cristão e o anarquista) como porta-vozes ou representantes de extratos declinantes na sociedade, de segmentos que, ao exprimirem sua indignação contra a sociedade ou o seu sofrimento perante a sociedade, revelam a sua incultura e vontade de vingança. Vingança, no caso, contra tudo o que é nobre, forte, criativo e edificante. Do sentimento de vingança, ou melhor, do seu ressentimento daquelas duas figuras, dado as suas incapacidades, fraquezas para dar consequências criativas ao seu viver, nascera um pendor destrutivo, condenatório que se notava em seus discursos e em suas preces. A condenação, em um ou em outro tipo decadente, contra o mundo ou contra a sociedade, era imaginada em nome de um além, como meio contra o aquém.

Esta moral da decadência, ascética, que se move pelo res-

11 Devemos salientar que a crítica nietzschiana às instituições liberais se desdobra nas interpretações sobre o homem moderno e a modernidade, cujas avaliações resultam em notas sobre os decadentes ou sobre a decadência, e decorrem da presença dominante de valores morais ascéticos, espraiados por todo o Ocidente por via do cristianismo, e também por meio das ideologias simpáticas ou da compaixão. 
sentimento, de acordo com o aforismo de número 35 (GD/CI, Crítica da moral da décadence 35, KSA 6.134), apresentada como moral "altruísta" (as aspas são de Nietzsche), como moral da compaixão, seja no cristianismo, seja na filosofia de Schopenhaeur, estão contaminadas por um juízo de valor sobre a vida, "nada tem valor - a vida não vale nada" (GD/CI, Incursões de um extemporâneo 35, KSA 6.134). No fundo, elas querem dizer: nós já não encontramos mais o nosso interesse, o nosso egoísmo, a nossa vantagem na vida. Trata-se de um sintoma da decadência de suas forças, de uma doença fisiológica, já que aquele corpo já não alcança uma ordem, seus instintos fundamentais estão desagregados. Por isso, a ilusão que produzem e que precisam produzir a partir da noção do "desinteresse", da impessoalidade e do não egoísmo.

Desse modo, em "se nos tornamos mais morais" (GD/CI, Incursões de um extemporâneo 37, KSA 6.136-139), ao contrário do que comumente se atribui ao homem moderno, à noção de progresso e à avaliação de superioridade em relação ao homem antigo, Nietzsche afirma presenciar nada mais que vida declinante e decadência. $\mathrm{O}$ homem moderno, com suas delicadezas e suscetibilidades, com sua fisiologia superexcitável, seu hedonismo e ao mesmo tempo com as virtudes do amor ao próximo, sua dedicação ao trabalho, sua impessoalidade, legalidade, cientificismo e acumulação econômica, suas pretensões de felicidade e bem-estar - esse homem não suportaria viver em épocas fortes, dominadas por um gosto e virtudes nobres. No tempo do Renascimento ou nas épocas mais ricas da nobreza grega, ele seria motivo de riso e do ridículo. Considerando o exposto, na época moderna vê-se o contrário de uma vida superior, em comparação com tempos mais ditosos.

O conjunto de valores e instintos presentes nas chamadas instituições liberais, que dominam a época moderna, seria a consequência necessária do homem moderno e sua época, sua fraqueza e decadência. Os princípios e objetivos que presidem o liberalismo são, antes de tudo, o oposto a uma vida que se tornou livre, ele representa em último grau o desdobramento da moral de rebanho, da 
domesticação dos homens, para certas sociabilidades nos limites implacáveis do Estado, e das demais formas institucionais tipicamente modernas, que inviabilizam o surgimento do indivíduo autônomo (GD/CI, Incursões de um extemporâneo 38, KSA 6.139-140).

A modernidade, por conseguinte, é avaliada no aforismo 39 (GD/CI, Incursões de um extemporâneo 39, KSA 6.140-142), como a época na qual predomina a forma declinante do Estado. Nela já não existem forças de vontade capazes de imperar sobre o caos dos instintos e dos interesses privados e dispersos. A capacidade organizadora e sobre-ordenadora com a qual se fundam instituições e se estabelecem compromissos entre gerações seria declinante em vias de desaparecimento e, em seu lugar, sucedia o espírito moderno com o laisser aller, o sentido da obsolescência, contra todo fundamento de autoridade. A título de exemplo, poderia ser usada a transformação da instituição do casamento e a sua constituição moderna a partir da idiossincrasia do sentimento amoroso e, por consequência, falência e impotência para pactos em nome das gerações do passado e do futuro.

$\mathrm{E}$ aqui retornamos a Sérgio Buarque. O autor brasileiro concordou com Nietzsche sobre a necessidade de algo mais que sentimentos para fundar uma sociedade. Na verdade, de modo geral, podemos notar em Holanda, confluências com o pensamento de Nietzsche, referentes às críticas ao liberalismo, especialmente quanto ao que, nas instituições modernas ocidentais, o racionalismo excedera as razões da vida. Ou, também, no amor às ideias fixas, ao criar um mundo fora do mundo, como horror e fuga à realidade vivida dos brasileiros em decorrência da crise, do enfraquecimento fisiológico, vital para uma "reação sã e fecunda" àquele estado de coisas (pois já não distinguem o próprio interesse!).

Mas, existe uma diferença construída na estratégia interpretativa de Holanda, possivelmente também por meio da leitura dos textos nietzschianos. A frase de Nietzsche "um povo perece, quando confunde seu dever com o conceito de dever em geral" (AC/AC: 
11, KSA 6.177), está inserida no contexto da crítica à cultura filosófica alemã, como desdobramento do senso teológico moral entre os alemães que ganhara, com o filósofo Kant, notoriedade entre os europeus.

Em Kant, de acordo com Nietzsche, o imperativo categórico na moral se impunha como um "tu deves", e subtraía a noção de prazer, fonte de justiça e fortalecimento da vida e traduzir-se-ia em outro produto derivado da visão dogmática cristã nihilista, ascética e contra a vida. O filósofo de Königsberg e a sua concepção da Revolução como movimento e forma da resposta moral da humanidade à suposta "tendência (da humanidade) para o bem" são interpretadas como provas da decadência da filosofia e da vida alemã. Em contraposição, para Nietzsche, não haveria uma resposta moral única, ou uma "tendência para o bem", nomeada de "revolução" a "virtude" impessoal e abstrata, a ser considerada adequada para todos os povos. Em contraposição o filósofo alemão assevera a cada povo inventar a sua personalíssima virtude.

Uma virtude tem de ser nossa defesa e necessidade personalíssima: em qualquer outro sentido é apenas um perigo. $O$ que não é condição de nossa vida a prejudica (...). A "virtude", o "dever", o "bom em si", o bom com o caráter da impessoalidade e validade geral - fantasias nas quais se exprime o declínio, o esgotamento final da vida, o chinesismo königsberguiano (AC/AC: 11, KSA 6.177).

Ora, a advertência nietzschiana para nos esquivar de tomarmos como próprio e pessoal, um dever impessoal, ou de maneira inversa, que as formas futuras da cultura e das instituições devem ter em conta, sobretudo, o que é nossa condição de vida, nos parece ter significado para Sérgio Buarque de Holanda, que a referida interjeição de Nietzsche a Kant sobre o imperativo categórico da moral devesse ser levada em conta, também, em relação ao uso extensivo das categorias críticas nietzschianas à modernidade. A questão, para o autor brasileiro, decorrente de uma lógica interpretativa, poderia ser assim formulada: as categorias críticas à modernidade europeia 
Farias, D

poderiam ser usadas com a mesma extensão na crítica ao liberalismo democrático e sua institucionalização na sociedade brasileira!?

A resposta talvez tenha sido negativa. A diferença residiria em que na Europa e também na América do Norte, onde o processo histórico desenvolvera determinadas formas de vida, emolduradas pela noção de "americanismo", tinha como elemento básico de suas configurações um "tipo" humano moderno, o self man e os valores do racionalismo, impessoalismo, metodismo e interesse privado.

Longe disso estaria o caso brasileiro. A cordialidade e seus fundamentos sentimentais caracterizariam o conjunto dos comportamentos brasileiros, tanto na esfera privada quanto pública, se é que fosse possível distingui-las entre nós. Diverso da maioria dos povos ocidentais do mundo setentrional, onde dominam as formas de um ideal de virtude advindo da noção de impessoalidade (muito embora Holanda, e provavelmente Nietzsche, as considerem apenas formalismos e ilusões a sombrear o real), no Brasil o caráter dominante da cultura e a condição própria da vida era o personalismo: “[...] toda a nossa conduta ordinária denuncia um apego aos valores da personalidade, configurada pelo recinto doméstico. Cada indivíduo se afirma ante os seus semelhantes, indiferente a lei da comunidade e atento apenas ao que o distingue dos demais, do resto do mundo" (HOLANDA, 1936, p. 113). Entre nós, uma vida emocional transbordante se superpõe a todo ritual formalístico, produto do dever moral estabelecido com a noção de equilíbrio ou ausência de egoísmo, máscaras das ideologias de justiça e igualdade do contratualismo liberal democrático. No homem cordial, o egoísmo e o interesse dos sentimentos prevalecem em todas as manifestações da sociedade.

Neste sentido, se em Nietzsche a análise coloca em termos antagônicos a vida e o liberalismo democrático da modernidade e insere, em uma perspectiva pessimista, o próprio homem moderno e sua cultura de "indivíduo cotidiano", característico da moral da compaixão, em Holanda, a crítica à ideologia liberal, em todas as 
suas formas, nos parece não ser extensiva aos valores da personalidade, "os únicos positivos entre nós", subjacentes às institucionalidades sociais e políticas da nação. Para o autor brasileiro, esses antigos valores seriam aptos a suportar, em um horizonte de expectativas, a criação, a invenção de virtudes personalíssimas, como asseverou Nietzsche na crítica a Kant.

Se é possível imaginarmos que aquela anterior citação de Nietzsche tenha inspirado Holanda a contrapor a cultura do personalismo versus os valores da impessoalidade, é porque o autor brasileiro avaliou a presença do liberalismo democrático tal qual uma superfetação à vida brasileira, infecundo e destrutivo das formas anteriores, sem ser capaz de criar algo novo, considerando-o desajustado às nossas condições de vida. Assim, os valores do personalismo, inerentes às manifestações da cordialidade, subsistem, resistem e poderiam ser "espiritualizados", para usar um termo nietzschiano, em um quadro de melhor consonância com a vida brasileira.

Já temos visto que o Estado, criatura espiritual, opõe-se à ordem natural e a transcende. Mas também é verdade que essa oposição deve revolver-se em um contraponto para que o quadro social seja coerente consigo. [...] 0 espírito não é um força normativa, salvo onde pode servir à vida social e onde lhe corresponde. As formas exteriores da sociedade devem ser como um contorno congênito a ela e dela inseparável: emergem continuamente das suas necessidades específicas e jamais das escolhas caprichosas (HOLANDA, 1936, p. 161).

A fortuna crítica de Raízes do Brasil aponta para a existência de impasse em relação ao que deveria ser uma proposição da concepção adequada da forma política para o Brasil. Talvez tenham razão, mas, é necessário observar o conjunto de negativas a variados movimentos e filosofias políticas de sua época: o liberalismo parlamentar, o socialismo, as formas caudilhas e dentre elas o fascismo. Posteriormente, quem sabe, pudéssemos imaginar, nas 
entrelinhas da obra, as possíveis intenções e predileções do autor. Nossa interpretação infere, em conclusão, que Holanda avaliou negativamente a presença formas liberais democráticas e seus valores compassivos, em lograr êxito definitivo e completo sobre os valores da cultura da personalidade considerados significativos na vida brasileira. Dessa avaliação, o autor imagina a necessidade da criação de outra forma política, mais consonante à vida nacional, que superasse a um só tempo as formas do impessoalismo liberal e os perigos do caudilhismo tirânico e despótico. Parece-nos que a perspectiva política de Sérgio Buarque conduzia a formas oligárquicas/aristocráticas!

\title{
Revolution and Nihilism in Raízes do Brasil, 1936
}

\begin{abstract}
Abstract: The article presents an approach to the theme "Revolução", debated by Holanda on his book "Raízes do Brasil" (1936). The analysis was based on Nietzsche's philosophy, by exploring concepts concerning bad consciousness, ascetic ideal and criticism of the modernity. Besides two explicit references to the philosopher, the embracing Nietzschian notions support Holanda's assessment of the "new times" in Brazil. Nonetheless, the Brazilian's criticism was targeted at those "liberal superfetation", owing to its exogenous feature to the Brazilian traditions. In contrast, he considered positively the values of personalism, implicit in our way of life, favorable to the invention of a politic shape as far as the society is concerned.
\end{abstract}

Keywords: revolution; nihilism; Nietzsche; Raízes do Brasil; Sérgio Buarque de Holanda 
Revolução e Nihilismo em Raízes do Brasil, 1936

\section{Referências}

HOLANDA, Sérgio B. Raízes do Brasil. Rio de Janeiro: Ed. José Olympio, 1936.

HOLANDA, Sérgio B. Viagem a Nápoles. In: MONTEIRO, Pedro Meira; EUGÊNIO, João Kennedy (Org.). Sérgio Buarque de Holanda: perspectivas. Campinas: Ed. da UNICAMP; Rio de Janeiro: Ed. da UERJ, 2008. p. 565582.

NIETZSCHE, Friedrich. Genealogia da Moral. Trad. Paulo César de Souza. São Paulo: Companhia das Letras, 1998.

NIETZSCHE, Friedrich. Crepúsculo dos Ídolos. Trad. Paulo César de Souza. São Paulo: Companhia das Letras, 2006.

NIETZSCHE, Friedrich. Assim falou Zaratustra. Trad. Paulo César de Souza. São Paulo: Companhia de Bolso, 2012.

NIETZSCHE, Friedrich. O Anticristo e Ditirambos de Dionísio. Trad. Paulo César de Souza. São Paulo: Companhia de Bolso, 2016.

SCALDAFERRO, Maikon Chaider Silva. A Família e o Estado: Antígona, Hegel e as raízes do Brasil. In: Griot: Revista de Filosofia. Amargosa, Bahia Brasil, v.14, n.2, Disponível em dezembro de 2016/www.urfb.edu.br/griot. Acesso em 2019.

SÓFOCLES, Antígona. Trad. Donaldo Schuler. Porto Alegre: L\&PM, 2011.

WAIZBORT, Leopoldo. O mal-entendido da democracia - Sérgio Buarque de Holanda, Raízes do Brasil, 1936. In: Revista Brasileira de Ciências Sociais. São Paulo. v. 26, n. 76, p. 39-62, 2011.

Enviado 09/02/2020

Aceito 10/04/2020

Cad. Nietzsche, Guarulhos/Porto Seguro, v.41, n.3, setembro-dezembro $2020 \mid 219$ 